\title{
Analysis of risk factors for falls among institutionalized elderly persons
}

Vitor Pena Prazido Rosa' ID

Fátima Cristina Bordin Dutra Cappellari² ${ }^{2}$ Janete de Souza Urbanetto ${ }^{1,2}$ (ID

\section{Abstract}

Objectives: to identify the demographic and clinical profile, context of risk and the occurrence of falls among institutionalized elderly persons; analyze the association between the classification of risk of falling using the Brazilian version of the Morse Fall Scale and the occurrence of falls in such individuals. Method: A cohort study was performed in two long-stay institutions in the city of Porto Alegre, Brazil. The sample consisted of 193 elderly persons. Descriptive and inferential statistics (Chi-squared and Fisher tests) were used for analysis. Results: The occurrence of falls was associated with hearing impairment, hand grip strength, Katz Index score, degree of dependence according to Collegial Board Resolution 283/2005 and risk of falls according to the MFS-B. Conclusion: Falls have multifactorial causes, which makes it important to identify the agents that contribute to their occurrence, as it is known that institutionalization significantly increases the risk of falling. Multidisciplinary actions are important for reducing the risk of falls, together with the use of instruments that can predict such risk among institutionalized elderly people.
Keywords: Patient Safety; Accidental Falls; Risk Factors; Elderly; Homes for the Aged.

\footnotetext{
Pontifícia Universidade Católica do Rio Grande do Sul, Escola de Medicina, Programa de Pós-graduação em Gerontologia Biomédica. Porto Alegre, Rio Grande do Sul, Brasil.

2 Pontifícia Universidade Católica do Rio Grande do Sul, Escola de Ciências da Saúde. Porto Alegre, Rio Grande do Sul, Brasil.

Funding: Conselho Nacional de Desenvolvimento Científico e Tecnológico (CNPq) - Programa Institucional de Bolsas de Iniciação Científica -Pibic/CNPq. 


\section{INTRODUCTION}

The Brazilian Ministry of Health ${ }^{1}$, through Ordinance ${ }^{\circ} 529$ dated April 1, 2013, established the National Program for Patient Safety (PNSP) for the monitoring and prevention of harm in healthcare. Among the objectives of the program are to create a culture of patient safety, implement safety practices and reduce events that cause harm to the patient. Nine thematic areas were established for the construction of protocols, guides and manuals for patient safety. One these areas is the prevention of falls.

According to the World Health Organization ${ }^{2}$, falls are defined as the event in which a person "comes to rest inadvertently on the ground or floor or other lower level, excluding an intentional change of position to rest on furniture, walls or other objects".

Generally, falls in patients are associated with factors related to both the individual and the environment. Factors related to the individual include advanced age; a recent history of falls; a reduction in mobility; urinary incontinence; use of medications and postural hypotension, while notable among environmental and organizational factors are uneven floors, objects dropped on the floor, inadequate chair height, insufficient or inadequate human resources ${ }^{3,4}$

Falls are the second leading cause of accidental or unintentional injury deaths worldwide. Each year, about 646,000 people die from falls around the world, $80 \%$ of whom live in underdeveloped or developing countries. Adults over 65 suffer a greater number of fatal falls. Each year, 37.3 million falls are severe enough to require medical attention ${ }^{5}$.

Several studies conducted over the years were analyzed by the Brazilian Society of Geriatrics, which classified the risk factors for falls into three categories: intrinsic factors, extrinsic factors and behavioral factors ${ }^{6}$.

Of adults hospitalized in Brazil for falls from November 2013 to November 2014, 25\% were elderly, while $63 \%$ of elderly patients who had fallen died as a result of their fall. According to data contained in the Protocol for the Prevention of Falls of the Brazilian Ministry of Health, "among patients who suffered falls there are reports of a greater occurrence in patients in transfer to long-term care environments"3.

In Brazil, there is no single meaning for a longterm care facility for the elderly (LTCF). Throughout its history, the origin appears linked to asylums or shelters, led by Sisters of Charity organizations ${ }^{8}$. Collegial Board Resolution (RDC) No 283/20059 defines a LTCF as a "governmental or nongovernmental institution of a residential nature, intended for the collective domicile of persons aged 60 or over, with or without family support, in freedom and dignity and with citizenship".

The risk of falls can be monitored by means of validated scales for this purpose, such as the Morse Fall Scale ${ }^{10}$ which was translated and adapted for Brazil in $2013^{11}$ and validated in $2016^{12}$. This scale was validated for use in hospitalized patients and there is no knowledge of its application in LTCFs, nor of the use of any other specific scale for this population.

Based on the above, there is a need to identify the risk behavior for falls among elderly residents of an LTCF, justifying the present study. The research was therefore guided by the following question: What is the risk scenario for falls, based on the Brazilian Version of the Morse Fall Scale, and the occurrence of such events?

The objective of the study was (1) to identify the demographic and clinical profile, context of risk, and occurrence of falls among institutionalized elderly persons and (2) to analyze the association between the Brazilian version of the Morse Fall Scale classification of risk and the occurrence of falls among such individuals.

\section{METHOD}

A prospective cohort study was performed, with initial data collection and follow-up and evaluation of the occurrence of falls over a nine month period. The study was developed in two LTCFs (LTCF 1 and LTCF 2) in the city of Porto Alegre, Rio Grande do Sul, Brazil, from April to December 2016. The choice of these institutions was due to the fact that they were the two largest 
LTCFs in the city. LTCF 1 was founded 87 years ago and is maintained mainly by the collaboration of the community, partner companies and service groups. It has a multiprofessional team that serves the elderly residents of the institution. It is one of the largest LTCFs in Rio Grande do Sul (RS) and houses elderly people in situations of vulnerability. LTCF 2, meanwhile, was founded 120 years ago, is a non-governmental, nonprofit organization with a multiprofessional service, and is considered the oldest LTCF in Rio Grande do Sul. The study population consisted of all the institutionalized elderly persons in the two LTCFs (235 individuals), 120 from LTCF 1 and 115 from LTCF 2. A sample calculation was performed to identify a suitable sample size for the study, considering a ratio of $50 \%$, a sample error of $5 \%$ and a $95 \%$ confidence interval, resulting in a minimum sample of 147 elderly persons. All the elderly individuals were invited to participate and those who met the criterion of possessing adequate cognitive conditions to answer the questions, according to the mini-mental state exam, were included, resulting in a total of 193 elderly persons. Twenty-three individuals did not agree to participate in the study and 19 were excluded due to possible cognitive decline.

Data were collected by trained academics and health professionals using a guiding operational manual. Data collection was performed through the direct evaluation of the elderly persons and their medical records. The instrument was composed of sociodemographic variables (age, gender, length of institutionalization, schooling) and risk factors for falls and occurrence of falls [evaluation of musculoskeletal problems; visual and hearing impairment; medical diagnostics; suitability of footwear; hand grip strength; medications used; assessment of activities of daily living using the KATZ index ${ }^{13}$; degree of dependence according to RDC N ${ }^{\circ} 283 / 2005^{9}$; the Brazilian version of the Morse Fall Scale (MFS-B) ${ }^{11,12}$ and the occurrence of falls.

Each elderly person was evaluated at the beginning of data collection, however, the trained staff also evaluated those individuals who fell after the first evaluation on a weekly basis. Musculoskeletal problems were defined as yes or no based on the physical evaluation of the elderly and those referred to in their medical records, while hearing and visual impairments were self-reported by the elderly. The diagnoses of illness and medications in use data were collected directly from the records of the elderly and classified into groups.

Footwear was assessed for suitability and categorized into appropriate (covers the back of the foot and heel and is securely attached to the foot; or those not wearing footwear due to being bedridden) and inadequate footwear (covers the dorsum of the foot and heel and is not securely attached to the foot, or footwear that covers neither the back of the foot nor the heel, or that covers the back of the foot but not the heel).

Muscle strength was evaluated by the application of the Handgrip Strength Test (HST), using a dynamometer and an office chair (without support on the sides). The two hands, both dominant and non-dominant, were measured. Measurement was carried out three times, alternating between the dominant and non-dominant hand, with timed rest intervals of one-minute between each measurement. For the classification of handgrip strength, the maximal force obtained in the dominant limb by gender was used. Elderly women with a maximum strength of $\geq 11 \mathrm{kgf}$ were classified as normal and those with a maximum strength of $<11 \mathrm{kgf}$ were considered to have reduced handgrip strength; while elderly men with a maximum strength of $\geq 18 \mathrm{kgf}$ were considered normal, and those with a maximum strength $<18 \mathrm{kgf}$ were considered to have reduced handgrip strength ${ }^{14}$.

The Katz Index is composed of six evaluative items: bathing, dressing, going to the toilet, transference, continence and feeding, which classify the elderly as either completely or partially dependent. All the elderly persons who were independent in the six evaluation items were classified as independent; those who were dependent in one to five items of the scale were classified as partially dependent and those who were dependent in all six evaluative items were considered totally dependent ${ }^{13}$.

The degree of dependence established in RDC No. 283/20059 was also measured, with the following classification: degree of dependence I - independent elderly persons, even if they require the use of self- 
help equipment; degree of dependence II - elderly persons who were dependent in up to three self-care activities of daily living, such as: feeding oneself, mobility, hygiene, who were not cognitively impaired or had a controlled cognitive disorder; degree of dependence III - dependent elderly persons requiring assistance in all self-care activities of daily living and/or who were cognitively impaired.

The Brazilian version of the Morse Fall Scale contains six evaluation items: history of falls (yes, has fallen in the last three months: 25 points, has not fallen in the last three months: zero points); secondary diagnosis (yes, has more than one diagnosis of illness: 15 points, not more than one diagnosis of illness: zero points); walking aid (does not use: zero points; totally bedridden: zero points; walks assisted by health professional: zero points; uses crutch/walking stick: 15 points; holds on to furniture/wall: 30 points); intravenous therapy/saline or heparinized intravenous device (does not use: zero points, yes, uses: 20 points); gait (normal/doesn't walk/completely bedridden/uses wheelchair: zero points; weak gait: 10 points; impaired/unsteady gait: 20 points); mental state (oriented/able to extent of capabilities/limitation: zero points; overestimates ability/forgets limitations: 15 points) ${ }^{12}$. The sum of the scores of each item generates a score for classification into low risk (0-24 points), moderate risk (25-44 points), high risk ( $\geq 45$ points) ${ }^{10,11}$.

Descriptive and inferential statistics techniques were used. The descriptive statistics used measures of central tendency and dispersion (mean and standard deviation) and absolute (n) and relative (\%) frequency. The inferential part consisted of tests of association (Chi-squared and Fisher's exact). A significance level of $95 \%(p \leq 0.05)$ was applied.

The research project complies with Resolution No. 466/2012 and Resolution No. 510/2016 and was approved by the Research Ethics Committee of the Pontifícia Universidade Católica of Rio Grande do Sul, under approval No. 1,303,603. All participants signed a Free and Informed Consent Form (FICF) and in cases where the elderly persons were unable to sign the form, authorization was requested from the legal guardian.

\section{RESULTS}

Of the 235 individuals assessed, 19 were excluded due to possible cognitive decline and 23 due to refusal, giving a total sample for this study of 193 institutionalized elderly persons. The mean age was $79.04( \pm 8.9)$ years, with a median of 80 years $(61$ 98). The majority were women ( $\mathrm{n}=121,62.7 \%)$. Regarding time spent in the LTCF, 64 (33.2\%) had lived in the facilities for up to two years; $62(32.1 \%)$, from 2.01 to 5.9 years, and $67(34.7 \%)$ had been institutionalized for more than six years. As for schooling of the institutionalized elderly persons, 65 (33.7\%) had an incomplete primary education, while the next largest group was illiterate elderly persons with $50(25.6 \%)$. A total of $27(14.0 \%)$ had completed elementary education; 20 (10.4\%) were literate; 16 $(8.3 \%)$ had completed high school; eight (4.1\%) had a university education and seven (3.6\%) elderly persons had an incomplete high school education.

Table 1 shows the data for the clinical variables related to visual and hearing impairment, diagnosis of pathologies, use of medications and classification of dependence or risk. The mean number of diagnoses of illness among the elderly was $3.6( \pm 2.3)$, with a median of 3.0 (0-11). The elderly persons took an average of $6.2( \pm 3.0)$ medications, with a median of $6.0(0-15)$. Of the 149 elderly people who were able to perform the HST test, the mean strength in $\mathrm{kgf}$ in the dominant limb was $11.6( \pm 7.3)$, with a median of $10.0(0.0-39.3)$

Table 2 presents the data for falls occurring after the first evaluation. Of the elderly persons evaluated, $53(27.5 \%)$ fell after the first evaluation and two fell seven times. The morning shift was when the greatest number of falls was concentrated and the bedroom was where the greatest number occurred.

Table 3 shows data on the occurrence of harm, as well as the type of harm (physical, psychological or social), environmental and personal factors, and the report of the categorized context of the falls of elderly persons who fell after the first evaluation. Of the 53 elderly patients who fell, half suffered some type of harm, with physical damage being the most common in elderly persons with some type of injury. 
Data on the association between falls and sociodemographic and clinical variables, such as visual and hearing impairment, number of diagnoses of illness, number of medications taken, as well as Katz score, degree of dependence, hand grip strength and risk of falls according to the MFS-B, are shown in Tables 4 and 5.
Falls were associated with some clinical variables, notably the Katz Index score, degree of dependence according to RDC $\mathrm{N}^{\circ} 283 / 2005$, and risk of falls assessed by the MFS-B.

Table 1. Clinical characteristics of institutionalized elderly persons $(\mathrm{N}=193)$ in two long-term institutions for the elderly. Porto Alegre, Rio Grande do Sul, 2016.

\begin{tabular}{|c|c|}
\hline Variables & $\mathrm{n}(\%)$ \\
\hline \multicolumn{2}{|l|}{ Visually impaired } \\
\hline Not impaired & $33(17.1)$ \\
\hline Impaired & $160(82.9)$ \\
\hline \multicolumn{2}{|l|}{ Hearing impaired } \\
\hline Not impaired & $87(45.1)$ \\
\hline Impaired & $106(54.9)$ \\
\hline \multicolumn{2}{|l|}{ Diagnosis of illnesses } \\
\hline No diagnosis & $15(7.8)$ \\
\hline Up to three diagnoses & $95(49.2)$ \\
\hline Four or more diagnoses & $83(43.0)$ \\
\hline \multicolumn{2}{|l|}{ Katz Index Score } \\
\hline Independent & $84(43.5)$ \\
\hline Partially Dependent & $51(26.4)$ \\
\hline Totally Dependent & $58(30.1)$ \\
\hline \multicolumn{2}{|l|}{ Degree of dependency } \\
\hline Degree of dependency 1 & $99(51.3)$ \\
\hline Degree of dependency 2 & $27(14.0)$ \\
\hline Degree of dependency 3 & $67(34.7)$ \\
\hline \multicolumn{2}{|l|}{ Suitability of footwear } \\
\hline Suitable & $108(56.0)$ \\
\hline Not suitable & $85(44.0)$ \\
\hline \multicolumn{2}{|l|}{ Number of drugs } \\
\hline Does not use medicines & $5(2.6)$ \\
\hline Up to four medications & $50(25.9)$ \\
\hline Five or more medications & $138(71.5)$ \\
\hline \multicolumn{2}{|c|}{ Handgrip Strength Test $(n=149)$} \\
\hline Reduced female & $75(50.3)$ \\
\hline Normal female & $19(12.8)$ \\
\hline Reduced male & $27(18.1)$ \\
\hline Normal male & $28(18.8)$ \\
\hline \multicolumn{2}{|c|}{ Risk of falls according to Brazilian version of Morse Fall Scale (MFS-B) } \\
\hline Low & $35(18.1)$ \\
\hline Moderate & $85(44.0)$ \\
\hline High & $73(37.8)$ \\
\hline
\end{tabular}


Table 2. Context of falls of institutionalized elderly persons who fell after the first evaluation in two LTCFs. Porto Alegre, Rio Grande do Sul, 2016.

\begin{tabular}{|c|c|}
\hline Variables & $\mathrm{n}(\%)$ \\
\hline \multicolumn{2}{|l|}{ Falls after 1st evaluation $(\mathrm{n}=193)$} \\
\hline Did not fall & $140(72.5)$ \\
\hline Fell & $53(27.5)$ \\
\hline \multicolumn{2}{|l|}{ Total falls } \\
\hline None & $140(72.5)$ \\
\hline One & $34(17.6)$ \\
\hline Two & $12(6.2)$ \\
\hline Three & $3(1.6)$ \\
\hline Four & $1(0.5)$ \\
\hline Five & $1(0.5)$ \\
\hline Seven & $2(1.0)$ \\
\hline \multicolumn{2}{|l|}{ Time of fall $(\mathrm{n}=53)$} \\
\hline Morning & $20(37.7)$ \\
\hline Evening & $9(17.0)$ \\
\hline Night & $15(28.3)$ \\
\hline Not reported & $9(17.0)$ \\
\hline \multicolumn{2}{|l|}{ Fall Type $1(\mathrm{n}=53)$} \\
\hline From own height & $28(52.8)$ \\
\hline From chair/sofa/wheelchair & $15(28.3)$ \\
\hline Not reported & $10(18.9)$ \\
\hline \multicolumn{2}{|l|}{ Fall type $2(\mathrm{n}=53)$} \\
\hline Fell to ground & $47(88.7)$ \\
\hline Did not reach ground - was supported or supported self & $5(9.4)$ \\
\hline Not reported & $1(1.9)$ \\
\hline \multicolumn{2}{|l|}{ Fall site $(\mathrm{n}=53)$} \\
\hline Recreation Room & $4(7.5)$ \\
\hline Refectory & $3(5.7)$ \\
\hline Courtyard & $5(9.4)$ \\
\hline Bathroom & $6(11.3)$ \\
\hline Consulting room & $1(1.9)$ \\
\hline Nursing area & $1(1.9)$ \\
\hline Bedroom & $24(45.3)$ \\
\hline Hall & $8(15.1)$ \\
\hline Not reported & $1(1.9)$ \\
\hline
\end{tabular}


Table 3. Characterization of the occurrence of harm and contributory factors for the risk of falls among institutionalized elderly persons who had suffered falls, from two long term care facilities for the elderly. Porto Alegre, Rio Grande do Sul, 2016.

\begin{tabular}{|c|c|}
\hline Variables & $\mathrm{n}(\%)$ \\
\hline \multicolumn{2}{|l|}{ Occurrence of harm $(\mathrm{n}=53)$} \\
\hline No harm & $26(49.0)$ \\
\hline Suffered harm & $27(51.0)$ \\
\hline \multicolumn{2}{|l|}{ Physical harm (n = 53) } \\
\hline No & $29(54.7)$ \\
\hline Yes & $24(45.3)$ \\
\hline \multicolumn{2}{|l|}{ Psychological harm $(\mathrm{n}=53)$} \\
\hline No & $43(22.3)$ \\
\hline Yes & $10(5.2)$ \\
\hline \multicolumn{2}{|l|}{ Social harm $(\mathrm{n}=53)$} \\
\hline No & $48(90.6)$ \\
\hline Yes & $5(9.4)$ \\
\hline \multicolumn{2}{|c|}{ Total specific physical harm $(\mathrm{n}=24)$} \\
\hline Edema & $2(8.3)$ \\
\hline Bruise & $3(12.5)$ \\
\hline Fracture & $2(8.3)$ \\
\hline Skin Lesion & $7(29.4)$ \\
\hline Local pain & $2(8.3)$ \\
\hline Edema/hematoma & $2(8.3)$ \\
\hline Hematoma/skin lesion & $2(8.3)$ \\
\hline Edema/hematoma/skin lesion & $2(8.3)$ \\
\hline Not reported & $2(8.3)$ \\
\hline \multicolumn{2}{|c|}{ Specific psychological harm $(n=10)$} \\
\hline Fear of falling & $6(60.0)$ \\
\hline Shame & $2(20.0)$ \\
\hline Crying & $1(10.0)$ \\
\hline Not reported & $1(10.0)$ \\
\hline \multicolumn{2}{|l|}{ Specific Social harm $(n=5)$} \\
\hline Removal from activities & $4(80.0)$ \\
\hline Not reported & $1(20.0)$ \\
\hline \multicolumn{2}{|l|}{ Environmental factors $(\mathrm{n}=53)$} \\
\hline Unsuitable gurneys & $10(18.7)$ \\
\hline Slippery floor & $8(15.1)$ \\
\hline Open wing division gate & $1(1.9)$ \\
\hline Defect with wheelchair & $1(1.9)$ \\
\hline Not reported & $33(62.4)$ \\
\hline \multicolumn{2}{|l|}{ Personal factors $(\mathrm{n}=53)$} \\
\hline Unsuitable shoes & $15(28.3)$ \\
\hline Shaking & $6(11.3)$ \\
\hline Not adhering to instructions & $14(26.4)$ \\
\hline Unaccompanied & $1(1.9)$ \\
\hline Visual impairment & $1(1.9)$ \\
\hline Not reported & $16(30.2)$ \\
\hline
\end{tabular}


Continuation of Table 3

\begin{tabular}{ll}
\hline Variables & $\mathrm{n}(\%)$ \\
\hline Fall context report $(\mathrm{n}=53)$ & \\
Imbalance & $12(22.6)$ \\
Not reported & $13(24.5)$ \\
Slipped & $12(22.6)$ \\
Tripped & $7(13.2)$ \\
No restraints & $2(3.8)$ \\
Shaking & $6(11.4)$ \\
Unsuitable bed & $1(1.9)$ \\
\hline
\end{tabular}

Table 4. Association between falls and sociodemographic and clinical variables of elderly persons institutionalized in two long term care facilities for the elderly (N=193). Porto Alegre, Rio Grande do Sul, 2016.

\begin{tabular}{|c|c|c|c|c|}
\hline \multirow[t]{2}{*}{ Variables } & \multirow[t]{2}{*}{$\mathrm{n}(\%)$} & \multicolumn{2}{|c|}{ Falls } & \multirow[t]{2}{*}{$p$} \\
\hline & & No - n $(\%)$ & Yes - n $(\%)$ & \\
\hline \multicolumn{5}{|l|}{ Gender } \\
\hline Women & $121(62.7)$ & $82(67.8)$ & $39(32.2)$ & $0.054^{*}$ \\
\hline Men & $62(37.3)$ & $58(80.6)$ & $14(19.4)$ & \\
\hline \multicolumn{5}{|l|}{ Age } \\
\hline Up to 79 years old & $96(49.7)$ & $73(76.0)$ & $23(24.0)$ & $0.278^{*}$ \\
\hline 80 years and over & $97(50.2)$ & $67(69.1)$ & $30(30.9)$ & \\
\hline \multicolumn{5}{|l|}{ Schooling } \\
\hline Illiterate & $50(25.6)$ & $36(72.0)$ & $14(28.0)$ & $0.277 * *$ \\
\hline Literate & $20(10.4)$ & $12(60.0)$ & $8(40.0)$ & \\
\hline Incomplete elementary education & $65(33.7)$ & $51(78.5)$ & $14(21.5)$ & \\
\hline Complete primary education & $27(14.0)$ & $17(63.0)$ & $10(37.0)$ & \\
\hline Incomplete high school education & $7(3.6)$ & $5(71.4)$ & $2(28.6)$ & \\
\hline Complete high school education & $16(8.3)$ & $11(68.8)$ & $5(31.3)$ & \\
\hline University graduate & $8(4.1)$ & $8(100.0)$ & $0(0.00)$ & \\
\hline \multicolumn{5}{|l|}{ Time in LTCF } \\
\hline 0 to 2 years in LTCF & $64(33.2)$ & $49(76.6)$ & $15(23.4)$ & $0.685^{*}$ \\
\hline From 2.01 to 5.9 years in LTCF & $62(32.1)$ & $44(71.0)$ & $18(29.0)$ & \\
\hline Over 5.91 years in LTCF & $67(34.7)$ & $47(70.1)$ & $20(29.9)$ & \\
\hline \multicolumn{5}{|l|}{ Diagnoses of illness } \\
\hline None & $15(7.8)$ & $12(80.0)$ & $3(20.0)$ & $0.261^{* *}$ \\
\hline Up to three diagnoses of illness & $95(49.2)$ & $73(76.8)$ & $22(23.2)$ & \\
\hline Four or more diagnoses of illness & $83(43.0)$ & $55(66.3)$ & $28(33.7)$ & \\
\hline \multicolumn{5}{|l|}{ Total medications } \\
\hline Does not use medications & $5(2.6)$ & $5(100.0)$ & - & $0.132^{* *}$ \\
\hline Up to four medications & $50(25.9)$ & $40(80.0)$ & $10(20.0)$ & \\
\hline$\geq$ Five medications (polypharmacy) & $138(71.5)$ & $95(68.8)$ & $43(31.2)$ & \\
\hline
\end{tabular}

* Pearson's Chi-Squared; ** Fisher's Exact. 
Table 5. Association of falls with clinical variables of institutionalized elderly persons $(\mathrm{N}=193)$ from two longterm care facilities for the elderly. Porto Alegre, RS, 2016.

\begin{tabular}{|c|c|c|c|c|}
\hline \multirow[t]{2}{*}{ Variables } & \multirow[t]{2}{*}{$\mathrm{n}(\%)$} & \multicolumn{2}{|c|}{ Falls } & \multirow[t]{2}{*}{$p$} \\
\hline & & $\mathrm{No}-\mathrm{n}(\%)$ & Yes $-\mathrm{n}(\%)$ & \\
\hline \multicolumn{5}{|l|}{ Visual impairment } \\
\hline No & $33(17.1)$ & $23(69.9)$ & $10(30.3)$ & $0.688^{*}$ \\
\hline Yes & $160(82.9)$ & $117(73.1)$ & $43(26.9)$ & \\
\hline \multicolumn{5}{|l|}{ Hearing impairment } \\
\hline No & $87(45.1)$ & $72(82.8)$ & $15(17.2)$ & $0.004 *$ \\
\hline Yes & $106(54.9)$ & $68(64.2)$ & $38(35.8)$ & \\
\hline \multicolumn{5}{|c|}{ Hand Grip Strength $(\mathrm{n}=149)$} \\
\hline Reduced female & $75(50.3)$ & $47(62.7)$ & $28(37.3)$ & $0.004 *$ \\
\hline Normal female & $19(12.8)$ & $16(84.2)$ & $3(15.8)$ & \\
\hline Reduced male & $27(18.1)$ & $19(70.4)$ & $8(29.6)$ & \\
\hline Normal male & $28(18.8)$ & $27(96.4)$ & $1(3.6)$ & \\
\hline \multicolumn{5}{|l|}{ Katz Index Score } \\
\hline Independent & $84(43.5)$ & $76(90.5)$ & $8(9.5)$ & $<0.001^{*}$ \\
\hline Partial dependency & $51(26.4)$ & $30(58.8)$ & $21(41.2)$ & \\
\hline Total dependency & $58(30.1)$ & $34(58.6)$ & $24(41.4)$ & \\
\hline \multicolumn{5}{|l|}{ Degree of dependency } \\
\hline Degree of dependency 1 & $99(51.3)$ & $87(87.9)$ & $12(12.1)$ & $<0.001 *$ \\
\hline Degree of dependency 2 & $27(14.0)$ & $17(63.0)$ & $10(37.0)$ & \\
\hline Degree of dependency 3 & $67(34.7)$ & $36(53.7)$ & $31(46.3)$ & \\
\hline \multicolumn{5}{|l|}{ Suitability of footwear } \\
\hline Suitable & $108(56.0)$ & $85(78.7)$ & $23(21.3)$ & $0.031 *$ \\
\hline Unsuitable & $85(44.0)$ & $55(64.7)$ & $30(35.3)$ & \\
\hline \multicolumn{5}{|l|}{ Risk of falls } \\
\hline Low risk & 35 (18.1) & $29(82.9)$ & $6(17.1)$ & $0.012^{*}$ \\
\hline Moderate risk & $85(44.0)$ & $67(78.8)$ & $18(21.2)$ & \\
\hline High risk & $73(37.8)$ & $44(60.3)$ & $29(39.7)$ & \\
\hline
\end{tabular}

* Pearson's Chi-squared.

\section{DISCUSSION}

The present study describes the demographic and clinical profile and the context of risk and the occurrence of falls among institutionalized elderly persons. The participants were mostly women. The predominance of women in LTCFs is due to the fact that this segment of the population has a longer life expectancy ${ }^{15}$.

A total of $34.7 \%$ of the elderly persons had been institutionalized for more than 5.9 years. A study carried out with elderly persons in an LTCF in the state of Bahia found that the predominant period of institutionalization was 1 to 10 years among the majority of the elderly ${ }^{16}$. The findings indicate that the majority of the elderly persons had low levels of schooling, with the largest proportion having an incomplete primary education, followed by illiterate individuals. This finding is similar to that of another study, which found that the majority of the elderly were illiterate $(25.5 \%)$ or had a low level of education $(59.6)^{17}$.

The majority of the elderly persons evaluated were visually impaired, however, this variable was not associated with the occurrence of falls. These data corroborate another study, which found that the majority of the elderly had problems with vision ${ }^{16}$. 
In terms of hearing impairment, more than half of the elderly persons had some degree of deficiency. These findings were associated with the occurrence of falls. This risk factor is related to senescence, when there is a decline in hearing; as the ear is also responsible for body balance, disturbances in this sense organ can cause the occurrence of falls. A study that evaluated the risk of falls in elderly people living at home reinforces this finding, as impaired hearing was associated $(p=0.001)$ with a high risk of falls ${ }^{18}$.

Almost half of the elderly persons had up to three diagnoses of illness. However, almost the same percentage had four or more such diagnoses, most frequently between four and seven. These data show that the elderly persons assessed had poor health conditions, which requires greater care from the professionals responsible for this population. While worrying, this factor was not associated with falls in the present study. A study conducted in a region of Minas Gerais showed that the majority of the elderly $(38.2 \%)$ had two to three types of diagnoses of illness ${ }^{19}$.

In the evaluation of performance by the Katz Index, it was found that the largest proportion of the elderly independently performed six items on the scale, while the next largest group was those who were totally dependent. The high degree of independence of the institutionalized elderly is due to the profile of one of the institutions, as it accepts only independent elderly persons.

The Katz Index score was associated with the occurrence of falls. Literature ${ }^{17,20}$ suggests that the elderly should be encouraged to perform their activities of daily living in order to maintain their independence longer, with institutionalization representing a limiting factor. A study that correlates the risk of falls and functional autonomy in institutionalized elderly persons shows that there is an association $(p=0.001)$ between the Katz Index score and the occurrence of falls ${ }^{20}$. In another study, in the evaluation of the performance of basic activities of daily living by the Katz Index, it was found that the majority of the elderly were independent $(93.6 \%)^{17}$.
In relation to the degree of dependency defined by RDC $\mathrm{N}^{\circ} 283 / 2005$, the greatest percentage of the elderly persons were classified as degree of dependency 1 , followed by degree of dependency 3. No studies were found relating the RDC $\mathrm{N}^{\circ}$ 283/2005 degree of dependency with the risk of falls. However, this classification was associated with the occurrence of falls. The purpose of RDC No. $283 / 2005$ is to define rules for the functioning of LTCFs in order to guarantee the elderly population the rights guaranteed by current legislation, seeking to prevent and reduce the health risks of elderly people living in LTCFs, as well as to define and implement what measures should be taken regarding the degree of dependence of this population. Thus, further studies are needed to address degree of dependence and its relation to falls, so that care can be increased to prevent falls in this population.

The present study found that the majority of the evaluated elderly persons had adequate footwear. However, the use of inadequate footwear has been found to be associated with falls. A study of 42 elderly persons who fell found that $36(85.7 \%)$ used inadequate footwear and only six (14.3\%) used adequate footwear ${ }^{21}$. The present study corroborates these data, reinforcing that this may be one of the contributory factors for falls. It is known that LTCFs receive footwear donations, which suggests a need for sorting the type of footwear received, in order to establish safety restrictions related to this item, which can be one of the factors that triggers falls in the elderly.

There is a greater predominance of the use of five or more mediations, which characterizes polypharmacy, which is defined as the simultaneous use of five or more medicines ${ }^{22}$. A small proportion of the elderly did not use any type of medication, while some elderly persons took 15 different types of medications in a single day. However, although the use of multiple medications and their possible interactions is alarming, this factor was not associated with falls in this study. The data corroborate two other studies, one in Belo Horizonte, Minas Gerais, which reported that $91.5 \%$ of the elderly were using medications ${ }^{20}$ and another study which tested the association between the quantity of medications used 
and the presence of falls, and found no significant statistical relationship ${ }^{16}$.

HST evaluation showed that the institutionalized elderly men and women have reduced strength in their dominant hand, and that this variable was associated with falls. HST measurement is one of the predictors for assessing the strength of the elderly and their functional capacity, and may be related to the risk of falls. A study with the elderly illustrated the difference between the hand grip strength means of elderly persons who fell and those who did not fall after institutionalization. A large part of the elderly persons residing in the community who had fallen had a lower HST score (11 to $20 \mathrm{kgf}$ ) than those who had not fallen (21 to $30 \mathrm{kgf})^{23}$.

Regarding the classification of the risk of falls defined by the MFS-B, the largest proportion of elderly participants of the study exhibited moderate risk, followed by the group with a high risk of the occurrence of falls. The risk of falls according to the MFS-B was associated with falls. The use of scales to evaluate the risk of falls may anticipate the identification of elderly individuals with a potential for falls. Although there are no studies that apply the MFS-B in LTCFs, it is widely used in the hospital environment to identify the risk of falls in hospitalized patients. A study using the MFS in the hospital context found that moderate and especially high risk was associated with the occurrence of falls $(p=0.000)^{24}$.

During the study a notifications book was created to record the falls that occurred in the two LTCFs, with the aim of identifying factors that could contribute to such events, in addition to the application of the MFS-B. In the period from April to December $2016,27 \%$ of the elderly participants in the study suffered falls, representing a high percentage for a population living in a LTCF. Of the 53 elderly people who suffered falls, 34 fell once, 12 fell twice and two fell seven times. This shows the need for the creation of surveillance measures among elderly persons who fall and prevention measures for those who had not fallen.

The highest occurrence of falls was during the morning shift, followed by the night shift. The morning is the period of greatest activity in institutions, during which the elderly perform their hygiene routines. The morning shift was also related to the occurrence of falls in other studies ${ }^{21}$.

As for the type of fall, falls from the individual's own height and falls to ground predominated. A fall from one's own height is described as a public health problem, as well as resulting in serious consequences for the elderly when they strike the ground. In relation to external factors, these falls can be predicted and avoided through health education and by providing a suitable environment for the institutionalized elderly persons.

The most frequent place for falls was the bedroom, followed by the hallways and bathrooms of the institutions. Knowing the location of the falls is important so that risk prevention initiatives can be taken, since there are numerous factors that predispose the elderly to falling. The same sites have been described in other studies with institutionalized elderly people ${ }^{21,25}$.

Harm from falls is poorly addressed in studies, especially psychological and social harm. In this study, half of the elderly presented some type of harm, which was classified as physical, psychological or social. In almost half, the elderly who fell exhibited physical harm, with skin lesions being the most frequent, followed by bruising. However, there were elderly individuals who exhibited up to three types of physical harm at the same time. Alvares et al. ${ }^{25}$ reported in their study that one of the main consequences of falls are ecchymosis or skin lesions. The psychological impact of falls can include fear of falling and loss of confidence, and both can result in social isolation ${ }^{26}$.

In the context of the fall itself, imbalance and slipping were reported by the elderly as the cause of the fall. Imbalance may be associated with factors of aging itself, while slipping is associated with environmental and personal factors. Factors that can be predicted. A study that described the reason for the occurrence of falls in the elderly found that imbalance and slipping are among the main factors ${ }^{25}$.

Limitations of the present study were the lack of a daily evaluation by the researchers. However, 
the care team was trained to apply the MFS-B and for the notification of the broader context of falls. Another aspect that needs further investigation in future studies is the analysis of elderly persons with cognitive impairment, in order to better understand the risk factors of falls in this population. Furthermore, as the MFS-B cannot be used for this segment, prediction studies should be performed, as one of the items of the scale relating to the use of an intravenous treatment device always scored zero, as the elderly persons in the LTCFs investigated did not use this type of treatment. These aspects constitute a limitation of the study and a gap in the research which future studies can fill.

\section{CONCLUSION}

The present study achieves the proposed objectives by describing factors associated with the occurrence of falls in institutionalized elderly persons. It has been observed that falls are a frequent occurrence in the life of the elderly and bring with

\section{REFERENCES}

1. Brasil. Portaria n 529 , de $1^{\circ}$ de Abril de 2013. Institui o Programa Nacional de Segurança do Paciente (PNSP). Saúde Legis. 2013. Disponível em: http:// bvsms.saude.gov.br/bvs/saudelegis/gm/2013/ prt0529_01_04_2013.html

2. Lunsford B, Wilson LD. Focus on: falls prevention. Am Nurs Today. 2015;10(7):27-39.

3. Brasil. Ministério da Saúde. Anexo 1: Protocolo prevenção de quedas [Internet]. [sem local]: [sem editor]; 2013 [acesso em 05 dez. 2016]. Disponível em: http://portalsaude.saude.gov.br/portalsaude/arquivos/ pdf/2013/Mai/06/protocolos_CP_n6_2013.pdf

4. Miake-Lye IM, Hempel S, Ganz DA, Shekelle PG. Inpatient fall prevention programs as a patient safety strategy: a systematic review. Ann Intern Med. 2013;158:390-6.

5. World Health Organization. Fact sheets [Internet]. [sem local]: WHO; 2018 [acesso em 23 out. 2018]. Disponível em: http://www.who.int/news-room/factsheets/detail/falls them the presence of harm, not only physical, which can impact the health of such individuals.

The factors associated with falls in the present study were also described in other studies, reinforcing the idea that there is no single causal agent of this event. In this way, multifactorial causes require knowledge of and adherence to multidisciplinary actions, in order to identify elderly persons at risk and establish effective and efficient prevention measures, with the purpose of reducing the harm related to this event. The classifications of risk in the Brazilian version of the Morse Fall Scale were associated with the occurrence of falls. However, this scale requires validation for use in long-term care facilities for the elderly. This study is in the implementation phase.

In view of the findings, the implementation of care protocols for the prevention of falls is recommended. These should employ a multidisciplinary approach to minimize the occurrence of this event, which is extremely harmful to elderly persons residing in longterm care facilities, and to ensure their general safety.
6. Sociedade Brasileira de Geriatria e Gerontologia. Quedas em idosos: prevenção [Internet]. [Rio de Janeiro]: SBGG; 2008 [acesso em 05 dez. 2016]. Projeto Diretrizes. Disponível em: http://sbgg.org.br/ wp-content/uploads/2014/10/queda-idosos.pdf.

7. Brasil. Ministério da Saúde. Indicadores e dados básicos 2015 [Internet]. Brasília, DF: DATASUS; 2015 [acesso em 05 dez. 2016]. Disponível em: http:// tabnet.datasus.gov.br/cgi/idb2012/matriz.htm

8. Camarano AA, Kanso S. As instituições de longa permanência para idosos no Brasil. Rev Bras Estud Popul [Internet]. 2013 [acesso em 26 out. 2018];27(1):1-5. Disponível em: http://www.scielo.br/ pdf/rbepop/v27n1/14.pdf

9. Brasil. Agência Nacional de Vigilância Sanitária. Resolução RDC n 283, de 26 de setembro de 2005. Aprova o Regulamento Técnico que define normas de funcionamento para as Instituições de Longa Permanência para Idosos. Diário Oficial da União. 27 set. 2005. Disponível em: http://sbgg.org.br/wpcontent/uploads/2014/10/rdc-283-2005.pdf 
10. Morse JM, Morse RM, Tylko SJ. Development of a scale to identify the fall-prone patient. Can J Aging.1989;8(4):366-77.

11. Urbanetto JS, Creutzberg M, Franz F, Ojeda BS, Gustavo AS, Bittencourt HR, et al. Morse Fall Scale: tradução e adaptação transcultural para a Língua Portuguesa. Rev Esc Enferm USP [Internet]. 2013 [acesso em 05 dez 2016];47(3):569-75. Disponível em: http://www.scielo.br/pdf/reeusp/v47n3/0080-6234reeusp-47-3-00569.pdf

12. Urbaneto JS, Pasa TS, Bittencourt HR, Franz F, Rosa VPP, Magnago TSBS. Análise da capacidade de predição de risco e validade da Morse Fall Scale versão brasileira. Rev Gaúch Enferm [Internet]. 2016 [acesso em 01 maio 2017];37(1-7). Disponível em: http://www.scielo.br/pdf/rgenf/v37n4/0102-6933rgenf-1983-144720160462200.pdf

13. Duarte YAO, Andrade CL, Lebrão ML. Índex de Katz na avaliação da funcionalidade dos idosos. Rev Esc Enferm USP [Internet]. 2007 [acesso em 05 dez. 2016];41(2):317-25. Disponível em: http://www.scielo. br/pdf/reeusp/v41n2/20.pdf

14. Eichinger FLF, Soares AV, Carvalho Júnior JM, Maldaner GA, Domenech SC, Borges Júnior NG. Força de preensão palmar e sua relação com parâmetros antropométricos. Cad Ter Ocup UFSCar [Internet]. 2015 [acesso em 05 dez. 2016];23(3):525-32. Disponivel em: http://dx.doi.org/10.4322/0104-4931.ctoA0610

15. Araújo Neto AH, Patrício ACFA, Ferreira MAM, Rodrigues BFL, Santos TD, Rodrigues TDB, et al. Falls in institutionalized older adults: risks, consequences and antecedents. Rev Bras Enferm. 2017;70(4):719-25.

16. Reis LA, Torres GV. Influência da dor crônica na capacidade funcional de idosos institucionalizados. Rev Bras Enferm [Internet]. 2011 [acesso em 01 jun. 2017];64(2):274-80. Disponível em: http://www. scielo.br/pdf/reben/v64n2/a09v64n2.pdf

17. Alencar MA, Bruck NNS, Pereira BC, Câmara TMM, Almeida RS. Perfil dos idosos residentes em uma instituição de longa permanência. Rev Bras Geriatr Gerontol [Internet]. 2013 [acesso em 01 jun. 2017];15(4):785-96. Disponível em: http://www.scielo. br/pdf/rbgg/v15n4/17.pdf

18. Smith AA, Silva AO, Rodrigues RAP, Moreira MASP, Nogueira JA, Tura LFR, et al. Assessment of risk of falls in elderly living at home. Rev Latinoam Enferm [Internet]. 2017 [acesso em 01 jun. 2017];25:2754. Disponível em: http://www.scielo.br/pdf/rlae/v25/ pt_0104-1169-rlae-25-e2754.pdf
19. CameloI LV, GiattiI L, Barreto MS. Qualidade de vida relacionada à saúde em idosos residentes em região de alta vulnerabilidade para saúde de Belo Horizonte, Minas Gerais. Rev Bras Epidemiol [Internet]. 2016 [acesso em 01 jun 2017];19(2):280-93. Disponível em: http://www.scielo.br/pdf/rbepid/ v19n2/1980-5497-rbepid-19-02-00280.pdf

20. Silva JMN, Barbosa MFS, Castro POCN, Noronha MM. Correlação entre o risco de queda e autonomia funcional em idosos institucionalizados. Rev Bras Geriatr Gerontol [Internet]. 2013 [acesso em 01 jun. 2017];16(2):337-46. Disponível em: http://www.scielo. br/pdf/rbgg/v16n2/13.pdf

21. Lojudice DC, Laprega MR, Partezani RAR, Júnior ALR. Quedas de idosos institucionalizados: ocorrência e fatores associados. Rev Bras Geriatr Gerontol [Internet]. 2010 [acesso em 01 jun. 2017];13(3):403-12. Disponível em: http://www.scielo. $\mathrm{br} / \mathrm{pdf} / \mathrm{rbgg} / \mathrm{v} 13 \mathrm{n} 3 / \mathrm{a} 07 \mathrm{v} 13 \mathrm{n} 3 . \mathrm{pdf}$

22. Guido ELR, Yoleisi GC, Sulay LA, Ormandi CM. Evaluación de la relación beneficio/riesgo en la terapéutica de pacientes geriátricos. Rev Cubana Farm [Internet]. 2002 [acesso em 05 jul. 2017];36(3):170-5. Disponível em: http://scielo.sld.cu/pdf/far/v36n3/ far05302.pdf

23. Macedo DO, Freitas LM, Scheicher ME. Handgrip and functional mobility in elderly with different levels of physical activity. Fisioter Pesqui [Internet]. 2014 [acesso em 01 jun. 2017];21(2):151-55. Disponivel em: http://www.scielo.br/pdf/fp/v21n2/pt_1809-2950fp-21-02-00151.pdf

24. Remor CR, Cruz CB, Urbanetto JS. Análise dos fatores de risco para queda de adultos nas primeiras 48 horas de hospitalização. Rev Gaúch Enferm [Internet] 2014 [acesso em 01 jun 2017];35(4):28-34. Disponível em: http://www.scielo.br/pdf/rgenf/ v35n4/pt_1983-1447-rgenf-35-04-00028.pdf

25. Alvares LM, Lima RC, Silva RA. Ocorrência de quedas em idosos residentes em instituições de longa permanência em Pelotas, Rio Grande do Sul, Brasil. Cad Saúde Pública [Internet]. 2010 [acesso em 01 jun 2017];26(1):31-40. Disponível em: http://www.scielo. br/pdf/csp/v26n1/04.pdf

26. Florence CS, Bergen G, Atherly A, Burns ER, Stevens JA, Drake C. Custos médicos de quedas fatais e não fatais em adultos mais velhos. JAGS. 2018;66(1):693-8. 